Textos 



\title{
Consentimento
}

\section{sem consentimento: a teoria e a prática da democracia}

\author{
NOAM CHOMSK
}

$\mathrm{U}$

MA SOCIEDADE DEMOCRÁTICA decente deveria ser baseada no princípio do consentimento dos governados. Essa idéia ganhou aceitação geral, mas pode ser contestada tanto por ser muito forte quanto por ser muito fraca. Muito forte, porque sugere que as pessoas devem ser governadas e controladas. Muito fraca, porque mesmo os governadores mais brutais precisam, em certa medida, do consentimento dos governados, e geralmente o obtêm não apenas à força.

Estou interessado aqui em como as sociedades mais livres e mais democráticas têm tratado tais problemas. Durante anos as forças populares têm procurado obter uma fatia maior na administração de seus interesses, com algum sucesso ao lado de muitas derrotas. Entretanto, desenvolveu-se um corpo instrutivo de pensamento para justificar a resistência da elite à democracia. Aqueles que esperam entender o passado e moldar o futuro bem fariam em prestar cuidadosa atenção não somente à prática mas também à moldura doutrinal que a escora

Essas questões foram tratados há 250 anos por David Hume (1) em obra considerada clássica. Hume estava intrigado com "a facilidade com que os muitos são governados pelos poucos e a submissão implícita com que os homens cedem os seus destinos aos seus governantes". Achava tal fato surpreendente, pois "a força sempre está do lado dos governados". Se as pessoas se dessem conta disso, sublevar-se-iam e derrubariam seus governantes. Chegou à conclusão de que o governo está baseado no controle de opinião, um princípio que "se estende aos governos mais déspotas e à maioria dos governos militares, bem como aos mais livres e mais populares".

Hume certamente subestimou a eficácia da força bruta. A versão mais precisa é que, quanto mais livre e popular um governo, mais se torna necessário contar com o controle de opinião para assegurar a submissão dos governados aos governantes.

Admite-se, pelo espectro, que o povo deve se submeter. Numa democracia, os governados têm o direito de consentir, mas nada mais além disso. $\mathrm{Na}$ terminologia do pensamento progressista moderno, a população é de espectadores, e não de participantes, à exceção de escolhas ocasionais feitas entre os líderes que representam o poder autêntico. Assim é a arena política. A população deve ser inteiramente excluída da arena econômica, na qual em grande parte se deter- 
mina o que acontece na sociedade. Aqui, o público não deve ter função alguma de acordo com a teoria democrática vigente.

Essas admissões têm sido contestadas através da história, mas as questões só ganharam força especial a partir do primeiro levante democrático na Inglaterra do século XVII. A agitação da época é freqüentemente descrita como um conflito entre Rei e Parlamento, mas, como é freqüentemente verdadeiro, parte significativa da população não queria ser governada por qualquer dos concorrentes ao poder, mas "por cidadãos como nós, que conhecem nossas necessidades, e não por fidalgos e cavalheiros, que desconhecem as necessidades do povo e irão somente nos oprimir", como declaravam em seus panfletos.

Tais idéias perturbaram muito os homens da melhor qualidade, como eles mesmos se intitulavam - os homens responsáveis, na terminologia moderna. Estavam preparados para conceder direitos ao povo, mas dentro de limites e ancorados no princípio de que "por povo não queremos dizer a ralé confusa e ignorante", explicavam. Mas como esse princípio fundamental da vida social poderia ser reconciliado com a doutrina do consentimento dos governados, doutrina que já não era então fácil de ser suprimida? Uma solução para o problema foi proposta por Hutcheson (2), famoso filósofo moral contemporâneo de Hume.

O filósofo argumentava que o princípio do consentimento dos governados não é violado quando os governantes impõem planos que são rejeitados pelo público, se mais tarde as massas estúpidas e preconceituosas consentirem calorosamente com o que foi feito em seu nome. Podemos adotar o princípio do consentimento sem consentimento, expressão usada posteriormente pelo sociólogo norte-americano Franklin Harry Giddings (3).

Hutcheson estava preocupado com o controle da plebe no interior do país, enquanto Giddings, com o fortalecimento da ordem no exterior. Na época, estava escrevendo sobre as Filipinas, que o exército dos Estados Unidos libertava, e libertando também várias centenas de milhares de almas das tristezas da vida - ou, como a imprensa colocou: “... massacrando os nativos à moda inglesa, a fim de que as criaturas desorientadas que a nós resistem, pelo menos respeitem nossas armas e, mais tarde, reconheçam que lhes desejamos liberdade e felicida$d e "$. Para explicar tais aspectos em tom adequadamente civilizado, Giddings engendrou seu conceito de consentimento sem consentimento: "se em anos vindouros [o povo conquistado] vier a admitir que a relação disputada fora pelo mais alto interesse de todos, será possível sustentar razoavelmente que a autoridade foi imposta com o consentimento dos governados, da mesma forma quando um pai impede a criança de correr para uma rua movimentada". Pelo exposto, podese captar o significado real da doutrina do consenso dos governados. O povo precisa se submeter aos seus governantes e, para tanto, basta que lhes dêem o consentimento sem consentimento. Dentro de um Estado tirânico ou sob domínio estrangeiro, pode-se usar a força. Quando os recursos à violência são limitados, o consentimento dos governados deve ser obtido pelo expediente chamado manufatura do consentimento pela opinião progressista e liberal. 
A enorme indústria de Relações Públicas, desde suas origens no início deste século, tem se dedicado ao controle da mente pública, como os líderes do mundo dos negócios descrevem a tarefa. Eles advertiram quanto aos "industriais que enfrentam riscos" na "recém-percepcão do poder político das massas" e à necessidade de empreender e ganhar "a derradeira batalha pela mente dos homens e doutrinar cidadãos com a história capitalista até que fossem capazes de repetir a estória com notável fidelidade". E certamente cumpriram a palavra, suscitando um dos temas centrais da história moderna. O fato de a indústria das Relações Públicas ter suas raízes e seus maiores centros no país que goza de maior liberdade é exatamente o previsto com a compreensão adequada da máxima de Hume.

Alguns anos depois de Hume e Hutcheson os descreverem, as questões causadas pela massa popular na Inglaterra estenderam-se às colônias rebeldes da América do Norte. Os Pais da Pátria (Founding Fathers) (4) também se sentiram perturbados, como os britânicos da melhor qualidade e quase com as mesmas palavras. Como um deles disse: "Quando menciono o público, eu quero dizer que aí incluo só a parte racional. O vulgar ignorante é tão incapaz de julgar os modos [do governo] como é incapaz de manejar suas rédeas".

"O povo é uma grande besta que precisa ser domada", declarou Alexander Hamilton (5). Fazendeiros rebeldes e independentes tinham de ser ensinados, às vezes à força, que os ideais dos panfletos revolucionários não deveriam ser levados demasiadamente a sério. O povo comum não poderia ser representado por cidadãos como eles mesmos [do povo], que sabem de suas agruras, mas por gente educada [da pequena nobreza], mercadora - advogados e outros homens responsáveis, aos quais poderia ser confiada a defesa de tal privilégio.

A doutrina reinante foi expressa claramente por John Jay, presidente da Corte Suprema e do Congresso Continental: "As pessoas que possuem o país deveriam governá-lo". Visto dessa forma, resta uma questão a ser resolvida: quem é o dono do país? A pergunta foi respondida pelo surgimento de corporações privadas e estruturas institucionais projetadas para protegê-las e sustentá-las, embora continue sendo uma difícil tarefa compelir o público a manter o papel de espectador.

Os Estados Unidos são certamente o caso mais importante para se analisar, se quisermos entender o mundo de hoje e de amanhã. Uma razão é o seu poder incomparável. Outra, as suas instituições democráticas estáveis. Além disso, os Estados Unidos estiveram tão próximos quanto possível de uma Tábula Rasa. A América pode ser "tão feliz quanto desejar", observou Thomas Paine (6) em 1776: "ela tem uma folha em branco sobre a qual escrever". As sociedades indígenas foram amplamente eliminadas. Os Estados Unidos conservam poucos resíduos de estruturas européias mais antigas, razão da relativa fraqueza do contrato social e dos sistemas de apoio que, freqüentemente, têm suas raízes nas instituições pré-capitalistas. E, numa extraordinária extensão, a ordem sóciopolítica foi consenciosamente delineada. Ao estudar história, não se pode cons- 
truir experimentos, mas os Estados Unidos estão tão próximos quanto possível de um caso ideal de democracia capitalista de Estado.

O seu principal designer, além do mais, era um astuto pensador político: James Madison. Madison salientou, nos debates sobre a Constituição, que se as eleições na Inglaterra "fossem abertas a todas as classes da população, o patrimônio dos proprietários de terra seria inseguro". Uma lei agrária logo teria lugar, "dando terra aos sem-terra". O sistema constitucional deveria ser delineado de forma a impedir tal injustiça e "assegurar os interesses permanentes do país, que são os direitos de propriedade". A responsabilidade primeira do governo é "proteger a minoria dos opulentos contra a maioria", declarou Madison. Este tem sido o princípio-guia do sistema democrático desde suas origens até hoje. Em debate público, Madison falava dos direitos das minorias em geral, mas era evidente que tinha em mente uma minoria especial, a dos opulentos, a qual deveria ser protegida contra a maioria. A teoria política moderna enfatiza sua crença de que num governo justo e livre os direitos tanto da propriedade quanto da pessoa devem ser [efetivamente] protegidos. Mas, neste caso também, é preciso examinar a doutrina mais cuidadosamente. Não há direitos DE propriedade, somente direitos $\grave{A}$ propriedade, isto é, direitos de pessoas com propriedades. Talvez eu tenha direito ao meu carro, mas meu carro não tem direitos. $\mathrm{O}$ direito à propriedade também difere de outros na medida em que a posse da propriedade de uma pessoa priva outra desse direito: se seu possuo o meu carro, você não o possui; mas numa sociedade justa e livre, minha liberdade de fala não limitaria a sua. $\mathrm{O}$ princípio madisoniano, então, é o governo preservar os direitos das pessoas em geral, mas fornecer garantias especiais e adicionais para os direitos de uma classe diferenciada de pessoas - os possuidores de propriedades.

Madison previu que a ameaça da democracia provavelmente se tornaria mais aguda com o tempo devido ao aumento na "proporção daqueles que trabalham sob todas as agruras da vida e, secretamente, aspiram a distribuição mais eqüitativa de suas bênçãos". Madison temia que esse contingente pudesse se tornar influente. Ele estava preocupado com os "sintomas de um espírito de nivelamento", que já aparecera e advertiu sobre o "perigo futuro", se o direito de voto colocasse o "poder sobre a propriedade nas mãos dos que não tinham parte nela". Não se pode esperar que "aqueles sem propriedade ou com esperança de adquiri-la concordem suficientemente com seus direitos", explicou Madison. Sua solução era manter o poder político nas mãos daqueles que "procedem da e representam $a$ riqueza da nação, o conjunto de homens mais capazes", em suas palavras, com o povo fragmentado e desorganizado.

O problema do espirito de nivelamento surge também no exterior, naturalmente. Aprendemos um bocado sobre a teoria democrática realmente existente, vendo como tal problema é percebido, especialmente em documentos internos secretos, nos quais os líderes podem ser mais francos e mais abertos.

Tomem o exemplo importante do Brasil, o colosso do Sul. Em visita realizada ao país em 1960 pelo presidente Eisenhower, ele assegurou aos brasileiros que 
"o nosso sistema de empreendimento privado socialmente cônscio beneficia o povo todo, donos e trabalhadores igualmente.... Em liberdade, o trabalhador brasileiro fica feliz, demonstrando as alegrias da vida num sistema democrático". O embaixador norte-americano acrescentou que a influência dos Estados Unidos tinha quebrado "a velha ordem na América do Sul", ao trazer "ideais revolucionários tais como educação obrigatória gratuita, igualdade perante a lei, sociedade relativamente sem classes, sistema de governo responsável e democrático, livre empresa competitiva, [e] padrão de vida fabuloso para as massas".

Mas os brasileiros reagiram rispidamente às boas novas trazidas pelos seus tutores do Norte. As elites latino-americanas são "como crianças", informou o secretário de Estado John Foster Dules ao Conselho Nacional da Segurança: "praticamente sem capacidade para autogoverno". Pior ainda, os Estados Unidos estão "irremediavelmente mais atrasados que os soviéticos no desenvolvimento do controle sobre as mentes e emoções de povos não-sofisticados". Dulles e Eisenhower expressaram sua preocupação pela "habilidade comunista de conseguir controle de movimentos das massas", uma habilidade que "não temos capacidade de reproduzir Eles apelam para os pobres, que sempre querem pilhar os ricos".

Em outras palavras, achamos difícil induzir as pessoas a aceitar a nossa doutrina de que os ricos devem pilhar os pobres, um problema de relações públicas ainda não resolvido.

O governo Kennedy enfrentou o problema mudando a missão das Forças Armadas da América Latina, que era de defesa hemisférica, para segurança interna, decisão que gerou conseqüências fatais, a começar pelo golpe militar no Brasil. As Forças Armadas brasileiras tinham sido consideradas por Washington como uma ilha de sanidade no país, e o golpe foi saudado pelo embaixador de Kennedy, Lincoln Gordon, como uma rebelião democrática. "É a única vitória mais decisiva da liberdade na metade do século XX", disse ele. Economista pela Universidade de Harvard, Gordon acrescentou que a vitória deveria "criar um clima muito melhor para investimentos privados", dando uma visão mais aprofundada do sentido dos termos liberdade e democracia.

Dois anos depois, o secretário da Defesa, Robert McNamara, informou a seus associados que "a política dos Estados Unidos para os militares da América Latina tem, de maneira geral, sido eficaz em atingir as metas para eles projetadas". Essa política melhorou "a capacidade da segurança interna e estabeleceu a predominância do exército militar dos Estados Unidos. Os militares latino-americanos entendem suas tarefas e estão equipados para persegui-las graças aos programas de ajuda militar e treinamento de Kennedy". Essas tarefas incluíam a derrubada dos governos civis, "sempre que, a juizo dos militares, a conduta desses líderes fosse injuriosa para o bem-estar na nação. Tais ações são necessárias no ambiente cultural latino-americano", explicaram os intelectuais de Kennedy. "E podemos confiar serem elas levadas a cabo eficazmente, agora que os militares receberam compreensão e orientação dos Estados Unidos para atingirem tais objetivos. Isso 
asseguraria resultado apropriado para a luta revolucionária pelo poder entre os grupos majoritários, que constituem a atual estrutura de classes, na América Latina, resultado que protegerá o investimento privado dos Estados Unidos e o comércio, a raiz econômica que está no âmago do interesse político dos Estados Unidos na América Latina".

O exposto foi extraído de documentos secretos, neste caso, do liberalismo de Kennedy. O discurso público é, naturalmente bem diferente. Se nos ativermos a ele, entenderemos pouco sobre o significado real de democracia, ou sobre a ordem global dos anos passados, bem como sobre o futuro, uma vez que as mesmas mãos continuam segurando as rédeas.

O estudo mais sério realizado sobre o tema, evidentemente, é a respeito dos fatos básicos. Os Estados de Segurança Nacional instalados e apoiados pelos Estados Unidos estão discutidos em importante livro de Lars Schoultz (7), um dos principais estudiosos de assuntos latino-americanos: "O objetivo deles", em suas palavras, "era destruir permanentemente uma perceptível ameaça à existente estrutura de privilégio sócio-econômico, eliminando a participação política da maioria numérica", a grande besta de Hamilton. O objetivo é basicamente o mesmo na sociedade nacional, embora os meios sejam diferentes.

O padrão continua hoje. A violadora campeã dos direitos humanos no hemisfério é a Colômbia, também a principal destinatária da ajuda e do treino militar dos Estados Unidos nos anos recentes. O pretexto usado é a guerra às drogas, mas isso é um mito, como regularmente relatam os principais grupos de direitos humanos, a Igreja, entre outros órgãos que têm investigado o chocante recorde de atrocidades e os laços estreitos entre traficantes de narcóticos, proprietários de terras, militares e associados paramilitares. O terror estatal devastou organizações populares e virtualmente destruiu o único partido político independente, assassinando milhares de ativistas, inclusive candidatos à presidência, prefeitos e outros. Não obstante, a Colômbia é saudada como uma democracia estável, revelando mais uma vez o que significa democracia.

Exemplo instrutivo em particular é a reação ao primeiro experimento com a democracia na Guatemala. Neste caso, o documento secreto está parcialmente disponível, de modo que sabemos bastante sobre o pensamento que guiou tal política. Em 1952 a CIA advertiu que "as políticas radicais e nacionalistas do governo" tinham ganho o "apoio e aquiescência" de quase todos os guatemaltecos. O governo estava "mobilizando o campesinato até então politicamente inerte e obtendo o apoio de massa para o atual regime", por meio de organização trabalhista, reforma agrária entre outras políticas, "identificadas com a revolução de 1944", que levantara "forte movimento nacional para libertar a Guatemala de ditadura militar, atraso social e colonialismo econômico que tinham sido a norma do passado". A política do governo democrático "inspirou a lealdade e harmonizou-se com o próprio interesse da maioria dos guatemaltecos politicamente conscientes". A inteligência do Departamento de Estado relatou que a liderança democrática "insistia na manutenção de um sistema político aber- 
to", assim permitindo aos comunistas "expandir suas operações e a apelar efetivamente para vários setores da população". Tais deficiências da democracia foram sanadas pelo golpe militar de 1954 e o reinado do terror a partir de então, estabeleceu-se com apoio em grande escala dos Estados Unidos.

Um rápido olhar sobre a realidade de outro ponto de vista, é fornecido pelo recente acordo do NAFTA (North American Free Trade Agreement) dificilmente pode ser considerado um acordo de livre comércio. Seus traços altamente protecionistas são principalmente uma tentativa de bloquear os competidores asiáticos e europeus. Para mencionar outro desvio do princípio, metade dos produtos dos Estados Unidos exportados para o México jamais entra no mercado mexicano, é simplesmente transferida de uma filial de uma firma norte-americana para outra, atravessando a fronteira para fazer uso de mão-de-obra mais barata e livrar-se de regulamentos ambientais e trabalhistas, retornando depois aos Estados Unidos como importações, mas sempre controlada pela mão visível da gerência central. Mas, pelo mesmo, o acordo foi norte-americano, de modo que o termo não é inteiramente falso.

Não é mais possível fazer previsões alvissareiras sobre o NAFTA e os benefícios que traz para todos. Defensores do acordo agora admitem que "o propósito subjacente do NAFTA não era promover o comércio mas cimentar as reformas econômicas do México" (Foreign Affairs). Seu objetivo era enclausurar o país nas reformas que tinham feito dele um milagre econômico - para os investidores norte-americanos e para os mexicanos ricos, enquanto a população submergia na miséria. "Bloqueando o México nessas reformas, espera-se, desviar-se-á o perigo detectado pela Oficina de Estratégias do Desenvolvimento da América Latina [realizada] em Washington em 1990: de que "uma abertura à democracia no México poria à prova a relação especial ao instalar um governo mais interessado em desafiar as bases econômicas nacionalistas dos Estados Unidos". A democracia será menos ameaçadora se as opções políticas estiveram fechadas. O programa neoliberal geral de "minimizar o Estado" tem o mesmo objetivo.

Os homens responsáveis que têm de lidar com as crianças do mundo enfrentam uma árdua tarefa; portanto, não é surpreendente que o impulso de promover a democracia, de Washington, seja geralmente ineficaz e freqüentemente limitado à retórica. Estou citando o mais importante estudo da cruzada de Washington pela democracia durante os anos Reagan, feito por Thomas Carothers (8), que escreve com a perspectiva de alguém de dentro que trabalhou nos programas do Departamento de Estado de Reagan. Carothers considera o programa sincero, embora um grande fracasso. Observa também esse fracasso ter sido sistemático: na América do Sul, em países onde a influência de Washington foi menor, houve progresso real em direção à democracia, a que, em geral, o governo de Reagan se opunha, posteriormente colhendo créditos quando o processo se tornou irresistível; onde a influência de Washington foi maior, o progresso foi menor. Nas palavras de Carothers, "os Estados Unidos deveriam manter a ordem básica... de sociedades bastante não-democráticas e evitar mudanças com base populista". Tal como seus predecessores, o governo Reagan "adotou políticas 
pró-democracia como um meio de aliviar a pressão para uma mudança mais radical, mas inevitavelmente buscou somente formas limitadas de cima para baixo de mudança democrática que não pusessem em risco as estruturas tradicionais de poder, com as quais os Estados Unidos têm se aliado há muito tempo".

Problemas semelhantes têm ocorrido com instituições internacionais. Inicialmente, as Nações Unidas constituíam um instrumento confiável da política dos Estados Unidos, e eram muito conceituadas. Mas a descolonização trouxe o que se pode chamar de "tirania da maioria". A partir de 1960 Washington tomou a liderança ao vetar resoluções do Conselho de Segurança (seguidos por Grã Bretanha e a boa distância França), votando sozinha ou com alguns poucos Estados clientes contra resoluções da Assembléia Geral. As Nações Unidas caíram em desagrado e artigos moderados começaram a aparecer na imprensa, questionando por que o mundo estava se opondo aos Estados Unidos; que os Estados Unidos estivessem se opondo ao mundo seria um pensamento por demais bizarro para ser levado em consideração.

Os Estados Unidos retiraram sua aceitação de jurisdição compulsória pela Corte Mundial por razões semelhantes. O Departamento de Estado explicou que, quando os Estados Unidos aceitaram a jurisdição após a guerra, a maioria dos membros da UN (Nações Unidas) "estava alinhada com os Estados Unidos e compartilhava de seus pontos de vista quanto à ordem mundial". Mas, já não mais. Agora, "muitos deles não podem ser contados entre os que compartilham de nossa opinião e essa mesma maioria freqüentemente se opõe aos Estados Unidos em importantes questões internacionais". Precisamos, portanto, "reservar para nós mesmos o poder de determinar se a Corte tem jurisdição sobre nós em determinado caso". Não permitiremos que a Corte julgue "disputas que envolvam questões que estão essencialmente dentro da jurisdição interna dos Estados Unidos, como determinam os Estados Unidos”. Estavam em debate as ações dos Estados Unidos contra a Nicarágua, mais tarde condenadas pela Corte como uso ilegal de força - isto é, terrorismo internacional -, mas dentro da jurisprudência interna dos Estados Unidos, como elas unilateralmente determina. O princípio foi recentemente confirmado por Madeleine Albright, embaixadora de Clinton nas Nações Unidas, que informou ao Conselho de Segurança que Washington agirá "multilateralmente, quando puder e unilateralmente, quando precisar".

Meus comentários sobre as raízes madisonianas dos conceitos predominantes de democracia foram injustos num aspecto importante. Assim como Adam Smith e outros fundadores do liberalismo clássico, Madison foi pré-capitalista, e anticapitalista em espírito. Esperava que os governantes fossem "estadistas iluminados" e "filósofos benevolentes", cuja sabedoria saberia discernir os verdadeiros interesses de seu país. Tais governantes iriam "refinar e ampliar o ponto de vista público", resguardando os verdadeiros interesses do país contra os males das maiorias democráticas, mas com esclarecimento e benevolência.

Madison, porém, logo percebeu o contrário: a minoria opulenta prosse- 
guiu usando seu recém-adquirido poder, como Adam Smith havia descrito alguns anos atrás. Eles estavam decididos a perseguir o que Smith chamou de máxima vil dos patrões: "Tudo para nós e nada para o povo". Por volta de 1792, Madison advertiu sobre o crescente estado capitalista em evolução estar "colocando a motivação de interesse privado no lugar do dever público", levando à "real dominação dos poucos sob a aparente liberdade dos muitos". Deplorava-os a audaz depravação dos tempos, à medida em que poderes privados "tornam-se o bando pretoriano do governo - seu instrumento e tirano ao mesmo tempo; subornando pela sua benesses e intimidando com clamores e associações". Eles lançaram sobre a sociedade o que chamamos política, como John Dewey (9) comentou mais tarde. Um dos maiores filósofos do século XX e uma figura de liderança do liberalismo norte-americano, Dewey salientou que a fala da democracia tem pouco conteúdo quando grandes negócios "governam a vida do país através do controle dos meios de produção, troca, publicidade, transporte e comunicação, reforçada pelo comando da imprensa, agentes de imprensa e outros meios de publicidade e propaganda". Sustentou ainda que, numa sociedade livre e democrática, os trabalhadores devem ser "os donos de seu próprio destino industrial", e não instrumentos alugados pelos empregadores, idéias que remontam ao liberalismo clássico e ao iluminismo e reaparecem constantemente em lutas populares tanto nos Estados Unidos quanto em outros países.

Muitas mudanças têm ocorrido nos últimos 200 anos, mas as palavras de advertência de Madison tornaram-se mais apropriadas, assumindo novo significado, com o estabelecimento de grandes tiranias privadas que receberam poderes extraordinários no começo deste século, principalmente das Cortes. Internamente, suas estruturas são essencialmente totalitárias; as teorias arquitetadas para justificá-las, freqüentemente por progressistas, estão baseadas em idéias que também sustentam o fascismo e bolchevismo. Tais estruturas obtêm grandes vantagens dos Estados que dominam amplamente, permanecendo "tanto instrumentos quanto tiranos", na frase de Madison. E elas ganharam controle substancial sobre as economias interna e internacional, bem como sobre os sistemas informacional e doutrinal, trazendo à mente outra preocupação de Madison: "Um governo popular, sem informação popular ou meios para adquiri-la, é apenas um Prólogo a uma Farsa ou a uma Tragédia, talvez às duas coisas".

Examinemos agora as doutrinas que foram arquitetadas para impor as formas modernas de democracia política, expressas com muita precisão por Edward Bernays (10), uma de suas relevantes figuras, em importante manual da indústria de Relações Públicas. Ele começa observando que "A manipulação consciente e inteligente dos hábitos organizados e opiniões de massa é um elemento importante na sociedade democrática". Para levar a cabo essa tarefa essencial "as minorias inteligentes devem fazer uso de propaganda contínua e sistemática", porque somente elas "entendem os processos mentais e padrões sociais das massas" e podem "mexer os fios que controlam a mente pública". Assim, a nossa sociedade "consentiu que a competição livre fosse organizada pela liderança e propaganda", um outro caso de consentimento sem consentimento. A propaganda proporciona à 
liderança um mecanismo para "moldar a mente das massas", para que elas lancem sua "força recém-obtida na direção desejada". A liderança pode arregimentar a mente pública em cada passo exatamente "como um exército disciplina o corpo de seus soldados". Este processo de "consentimento manipulado é a própria essência do processo democrático", escreveu Bernays um pouco antes de ser agraciado, pela Associação Psicológica Americana, em 1949, por suas contribuições.

Como um bom liberal do New Deal (11), Bernays tinha desenvolvido suas aptidões no Comitê Woodrow Wilson sobre Informação Pública, a primeira agência de propaganda governamental dos Estados Unidos. "Foi o espantoso sucesso da propaganda durante a guerra que abriu os olhos da minoria inteligente de todos os setores da vida à possibilidade de se arregimentar a mente pública”, explicou Bernays em seu manual de Relações Públicas, intitulado Propaganda. A minoria dos inteligentes talvez não tivesse consciência de que o seu "espantoso sucesso" dependia, em não pequena escala, da fabricação de propaganda sobre as atrocidades dos Hunos, fornecidas pelo Ministério de Informação Britânico que, secretamente, definia sua tarefa como "dirigir o pensamento da maioria do mundo".

Tudo isso corresponde à doutrina wilsoniana, conhecida como idealismo wilsoniano em teoria política. A visão de Wilson era a de que uma elite de cavalheiros com ideais elevados seria necessária para preservar a estabilidade e a retidão: "É a minoria inteligente de homens responsáveis que deve controlar a tomada de decisões", explicou Walter Lippmann (12), um veterano da Comissão de Propaganda, em seus influentes ensaios sobre democracia. Lippmann foi também a figura mais respeitada do jornalismo norte-americano e célebre comentarista de assuntos públicos durante meio século. "A minoria inteligente é uma classe especializada, responsável pelo estabelecimento da política e pela formação de uma sólida opinião pública", postulou Lippmann. "Ela deve estar livre de interferência do povo, que é de estranhos intrometidos e ignorantes". O público tem de ser "posto no seu lugar", continuou Lippmann: "sua função é ser espectador de ação e não de participante, a não ser em práticas eleitoriais periódicas, quando ele escolhe entre a classe especializada". Os líderes devem ser livres para operar em insulação tecnocrática, para usar terminologia corrente do Banco Mundial.

Na Enciclopédia de Ciências Sociais, Harold Lasswell (13), um dos fundadores da ciência política moderna, advertiu que "a minoria dos inteligentes" precisa reconhecer a "ignorância e estupidez das massas" e não "sucumbir aos dogmatismos democráticos de os homens serem os melhores juizes de seus próprios interesses. Eles não são os melhores juizes, nós é que somos. As massas precisam ser controladas para seu próprio bem, e em sociedades mais democráticas, nas quais a força não é disponível, os gerenciadores sociais precisam se voltar amplamente para uma técnica de controle completamente nova, grandemente através da propaganda”.

Observe-se ser essa uma boa doutrina leninista. A semelhança entre a teoria democrática progressista e o leninismo-marxismo é um tanto surpreendente, aspecto que Bakunin já havia predito há muito. 
Os temas têm ressonância no período corrente; por exemplo, quando o professor Samuel Huntington - que leciona Ciência do Governo, em Harvard explicou, no início dos anos Reagan, que "pode se ter de pregar a intervenção, ou outra ação militar, de modo tal que se crie a falsa impressão de ser a União Soviética que se está combatendo. É o que os Estados Unidos estão fazendo desde a Doutrina Truman" (14). "Outra lição da ciência do governo", continua o mesmo estudioso, "é que os arquitetos do poder precisam criar uma força que possa ser sentida, mas não vista. O poder permanece forte quando está no escuro; exposto à luz do sol, começa a evaporar".

Para estruturar o consentimento dos governados é necessário não apenas iludi-los sobre a política, mas também esconder as forças que lançam a sombra chamada política. É responsabilidade dos intelectuais levar a cabo essas exigentes tarefas.

Com a compreensão adequada do conceito de consentimento podemos ver que a implementação da agenda comercial, apesar das objeções do público, é feita com o consentimento dos governados, uma forma de consentimento sem consentimento. É uma boa descrição do que está acontecendo nos Estados Unidos. Existe freqüentemente um hiato entre as preferências do povo e a política pública. Nos anos recentes tal hiato tornou-se substancial. A seguinte comparação lança mais luz sobre o funcionamento do sistema democrático: mais de $80 \%$ do povo acha que o governo é administrado para o benefício de poucos e de interesses especiais, e não para ele mesmo; até anos anteriores, eram mais de 50\%. Mais de $80 \%$ acredita que o sistema econômico é inerentemente injusto e os trabalhadores têm pouca influência sobre o que acontece no país. Mais de $70 \%$ sente que os negócios ganharam grande poder em muitos aspectos da vida norte-americana. De 20 a $21 \%$ do público acreditam que as corporações deveriam sacrificar um pouco do lucro para melhorar a vida de seus trabalbadores e comunidades.

As atitudes públicas permanecem teimosamente social-democráticas em detalhes importantes, como o fizeram nos anos Reagan, contrariamente à boa dose da mitologia. Mas precisamos também observar que essas atitudes estão longe das idéias que animaram revoluções democráticas. Os trabalhadores da América, do século XIX, não pleiteavam mais benevolência de seus empregadores. Antes, negavam seu "direito de governar". "Os que trabalham em fábricas deveriam ser donos delas", exigia a imprensa trabalhista, defendendo os ideais da revolução norte-americana como a turba perigosa os entendia".

A eleição dos membros do Congresso, em 1944, é exemplo revelador da distância entre retórica e fato. Foi chamada de "terremoto político, uma vitória política arrazadora, um triunfo do conservadorismo" que reflete o contínuo "desvio para a direita", quando os eleitores deram um "mandato popular esmagador" ao novo exército da ultra direita de Newt Gingrich (15), que prometeu "tirar o governo de nossas costas e trazer de volta os dias felizes de quando reinava o livre mercado". 
Voltando aos fatos, a vitória arrasadora foi obtida com apenas pouco mais da metade dos votos, cerca de $20 \%$ do eleitorado, dados que pouco diferem dos de dois anos antes, quando os Democratas ganharam. Entre os $20 \%$ que votaram pelo triunfo do conservadorismo, um em cada seis descreveu o resultado como "uma afirmação da agenda Republicana. "Da minoria que chegou a votar, só um entre quatro tinha ouvido falar do Contrato com a América que apresentava tal agenda. E, quando informada, a população se opôs virtualmente a quase tudo, em grande maioria. Cerca de $60 \%$ do público queria a despesa social aumentada. Um ano depois, $80 \%$ dele sustentava que "o governo federal deveria proteger os mais vulneráveis da sociedade, especialmente os pobres e idosos, garantindo-lhes um padrão mínimo de vida e oferecendo-lhes benefícios sociais". De 80 a $90 \%$ dos norte-americanos apoiam garantias federais de assistência pública para os que não podem trabalhar, seguro desemprego, receitas subsidiadas de drogas e casas de repouso para os idosos, nível mínimo de assistência à saúde e à previdência social. Três quartos do público apoiam assistência federal garantida à criança de mães que trabalham recebendo baixos salários. A elasticidade dessas atitudes é particularmente marcante à luz do constante assalto da propaganda, persuadindo o povo de que ele tem opiniões completamente diferentes.

Estudos realizados sobre opinião pública revelam que quanto mais os eleitores sabem sobre o programa republicano no Congresso, mais se opõem ao partido e seu programa no Congresso. O porta estandarte da revolução, Newt Gingrich, não era popular à época de seu triunfo, e sua popularidade caiu ainda mais, tornando-se talvez a figura política mais impopular do país. Um dos aspectos mais cômicos das eleições de 1996 foi a cena dos companheiros mais chegados a Gingrich, lutando para negar qualquer conexão de seu líder com suas idéias. Nas eleições primárias, o primeiro candidato a desaparecer, virtualmente de repente, foi Phil Gramm, o único deputado dos republicanos do Congresso, fundamentando muito bem suas palavras, ao dizer o que sabia agradar aos eleitores, de acordo com as manchetes. De fato, quase toda a gama das questões políticas desapareceu instantaneamente, assim que os candidatos tiveram de enfrentar os eleitores, em janeiro/96. O exemplo mais dramático foi o equilíbrio do orçamento. Durante o ano de 1995, a principal questão no país foi como fazê-lo de forma rápida, em sete anos ou um pouco mais. As atividades do governo foram paralisadas várias vezes, enquanto a controvérsia grassava. Assim que as eleições primárias ocorreram, o debate sobre o orçamento acabou. O Wall Street Journal relatou, com surpresa, que os eleitores "tinham abandonado sua obsessão por orçamento equilibrado" - isto é, sua oposição a equilibrar o orçamento com a previsão realística mínima, como as urnas tinham mostrado regularmente.

Para ser exato, parte do público compartilhava da obsessão dos dois partidos políticos com o equilíbrio do orçamento. Em agosto de 1995, o déficit foi indicado como o problema mais importante do país por $5 \%$ da população, equiparando-se com o da falta de habitação. Mas, entre os $5 \%$ obcecados pelo orçamento, estavam incluídas pessoas importantes. O comércio norte-americano manifestou-se: "equilibre o orçamento federal", conforme anunciou o Business 
Week, comunicando um escrutínio de executivos senior. E quando o comércio se manifesta, assim também o fazem a classe política e a mídia; esta informou ao público que os políticos exigiam um orçamento equilibrado, especificando os cortes na despesa social de acordo com o desejo público - sem levar em conta sua oposição substancial, como demonstraram as urnas. Não é de se admirar que o tema tenha desaparecido de repente, assim que os políticos tiveram de enfrentar a grande besta...

Também não é de se admirar que a agenda continue a ser implementada à sua moda padrão de dois gumes: com cortes cruéis e freqüentemente impopulares nos gastos sociais, ao lado de aumentos no orçamento do Pentágono, a que o público se opõe, mas com forte apoio do mundo dos negócios em ambos os casos. Os motivos para o aumento de despesas são facilmente compreensíveis quando temos em mente o papel doméstico do sistema do Pentágono: transferir fundos públicos para setores avançados da indústria, a fim de que os constituintes ricos de Newt Gingrich, por exemplo, possam ser protegidos dos rigores do mercado com mais subsídios do governo do que qualquer outro distrito suburbano no país, enquanto o líder da revolução conservadora condena o grande governo e enaltece o individualismo austero.

Desde o começo, fica claro pelas urnas que as estórias sobre a derrocada do conservadorismo foram falsas. Agora a fraude é tacitamente admitida. O especialista em votação dos republicanos de Gingrich explicou que, quando ele anunciou maioria do povo apoiar o Contrato com a América, queria dizer que os eleitores gostavam dos slogans usados como rótulo. Por exemplo, seus estudos mostravam que o público se opõe ao desmantelamento do sistema de saúde, mas que quer preservá-lo, protegê-lo e fortalecê-lo para a geração seguinte. Assim, desmantelar é rótulo de solução que preserva e protege o sistema de saúde para a geração seguinte. O mesmo é verdade em geral.

Todo o exposto é muito natural numa sociedade que, em grau incomum, é movida a negócios, com enorme despesa em marketing: US\$ 1 trilhão por ano, a sexta parte do produto interno bruto, na sua maioria dedutíveis de impostos, de modo a que as pessoas paguem pelo privilégio de estar sujeitas à manipulação de suas atitudes e de seu comportamento.

Mas a grande besta é difícil de ser domada. Repetidamente tem-se pensado que o problema foi resolvido e que o fim da história foi alcançado, numa espécie de utopia dos patrões. Momento clássico foi o das origens da doutrina neoliberal no começo do século XIX, quando Ricardo (16), Malthus (17), entre outras grandes figuras da economia clássica, anunciaram que a nova ciência tinha provado, com a certeza das leis de Newton, que os pobres só eram prejudicados ao se tentar ajudá-los; e o melhor presente que poderia ser oferecido às massas sofredoras seira libertá-las da ilusão de que têm direito à vida. A nova ciência provou que o povo não tinha direitos além dos que pudesse obter no mercado de trabalho não-regulado. Perto da década de 1830 parecia, na Inglaterra, que as doutrinas tinham vencido. Com o triunfo do pensamento correto a serviço dos interesses 
britânicos de manufatura e financeiros, o povo do país foi "forçado no caminho de um experimento utópico", conforme escreveu Karl Polannyi (18), em obra clássica, "o ato mais cruel da reforma social" em toda a história, que "esmagou multidões de vidas". Mas surgiu um problema imprevisto: as massas não-inteligentes começaram a inferir: "se não temos o direito de viver, então vocês não têm o direito de governar". O exército britânico teve de enfrentar tumultos e desordem, e logo uma ameaça ainda maior se esboçou, quando os trabalhadores começaram a se organizar exigindo leis de fábrica e legislação social para protegêlos do brutal experimento neoliberal, muitas vezes indo ainda além. A ciência, que felizmente é flexível, tomou novas formas quando a opinião da elite mudou em reação às incontroláveis forças populares, descobrindo que o diveito de viver tinha de ser preservado sob uma espécie de contrato social.

Mais para o fim do século, parecia a muitos que a ordem havia sido restabelecida, embora alguns discordassem. O famoso artista William Morris (19) ultrajou a opinião respeitável ao declarar-se socialista numa palestra em Oxford. Ele reconhecia que "era opinião aceita que o sistema competitivo, ou salve-se quem puder, é o último sistema de economia que o mundo verá; é um sistema perfeito e, portanto, a finalidade foi com ele atingida". "Mas se realmente a história está no fim", continuou ele, "então a civilização morrerá" Morris recusava-se a acreditar nisso, a despeito de proclamações confidentes dos homens mais doutos. Ele tinha razão, como as lutas populares o demonstraram.

Nos Estados Unidos também, os alegres 90 há um século foram aclamados como perfeição e finalidade. E perto dos loucos anos 20 assumiu-se confiantemente que a classe trabalhista tinha sido esmagada para sempre, e a utopia dos patrões realizada - em "uma mais do que não-democrática América, criada por cima dos protestos dos trabalhadores", segundo comenta David Montgomery, historiador da Universidade de Yale. Mas, novamente, a comemoração foi prematura. Em poucos anos a grande besta mais uma vez escapou de sua jaula e, mesmo os Estados Unidos, com a sociedade gerida pelos negócios por excelência, foram forçados pela luta popular a conceder direitos que tinham sido obtidos há muito tempo nas sociedades mais autocráticas.

Imediatamente após a segunda Guerra Mundial, o mundo dos negócios lançou enorme propaganda ofensiva para recuperar o que tinha perdido. No fim da década de 50 presumia-se, em larga escala, que o objetivo tinha sido alcançado. "Tínhamos chegado ao fim da ideologia", escrevera Daniel Bell, sociólogo de Harvard. Alguns anos antes, como editor do jornal Fortune, líder em assuntos de negócios, tinha anunciado a tremenda escalada das companhias de propaganda de comércio destinadas a sobrepujar as atitudes democráticas que persistiam nos anos pós-guerra.

Mais uma vez, porém, a festa fora prematura. Acontecimentos dos anos 60 demonstraram que a grande fera ainda estava à espreita, de novo fazendo surgir o medo da democracia entre os homens responsáveis. A Comissão Trilateral, fundada por David Rockefeller (20) em 1973, dedicou seu primeiro e mais impor- 
tante estudo à crise da democracia por todo o Oeste, ao mesmo tempo em que vastos setores da população procuravam entrar na arena política. Os ingênuos poderiam imaginar que o fato fosse um passo em direção à democracia, mas a Comissão entendeu ter sido democracia em excesso e procurou restabelecer os dias em que "Truman tinha sido capaz de governar o país com a colaboração de número relativamente pequeno de advogados e banqueiros de Wall Street", como comentou um rapporteur norte-americano. Isso era uma adequada moderação na democracia. De particular interesse para a Comissão foram os fracassos das chamadas instituições responsáveis pela doutrinação dos jovens: escolas, universidades e igrejas. A Comissão propôs meios para restabelecer a disciplina e fazer o povo retornar à passividade e à obediência, superando a crise de democracia.

A Comissão representava os setores internacionalistas mais progressistas do poder e da vida intelectual nos Estados Unidos, na Europa e no Japão: o governo Carter foi tirado quase que totalmente de suas fileiras. A ala direita tomara uma linha muito mais severa.

A partir de 1970, mudanças na economia internacional puseram novas armas nas mãos dos patrões, capacitando-os para esfacelar o odiado contrato social que tinha sido obtido pela luta popular. O espectro político nos Estados Unidos, sempre muito estreito, reduziu-se à quase invisibilidade. Alguns meses depois de Clinton ser empossado, o artigo de fundo do Wall Street Journal expressava seu prazer dizendo que "em uma questão após outra, o presidente Clinton e seu governo decidem apoiar a América corporativa", arrancando vivas dos cabeças das corporações mais importantes, que estavam encantados "porque estamos nos dando muito melhor com esta administração do que com as anteriores", segundo $\mathrm{o}$ artigo.

Um ano depois os líderes do comércio descobriram que poderiam sair-se ainda melhor, e pouco antes de setembro de 1995, o Business Week anunciou que o novo Congresso "representa um marco para os negócios: nunca antes coisas boas tinham sido derramadas tão entusiasticamente sobre os empresários americanos". Nas eleições de novembro de 1966 os dois candidatos eram republicanos moderados e de longa data íntimos do governo, candidatos do mundo dos negócios. A campanha foi um "tédio histórico", relatou a imprensa especializada em comércio. Os votos demonstraram que o interesse político tinha declinado ainda mais, além dos baixos níveis anteriores, apesar de as despesas terem batido recordes, e os eleitores não gostarem de qualquer dos candidatos e pouco esperarem deles.

Há descontentamento em larga escala com o funcionamento do sistema democrático. Fenômeno similar foi observado na América Latina, e embora as condições sejam bem diferentes, alguns dos motivos são os mesmos. Atílio Boron, cientista político argentino, acentuou o fato de que na América Latina o processo democrático foi estabelecido juntamente com as reformas econômicas neoliberais, desastrosas para a maioria das pessoas. A introdução de programas similares no país mais rico do mundo teve efeitos similares. Quando mais de $80 \%$ 
da população percebe que o sistema democrático é uma vergonha e que a economia é inerentemente injusta, o consentimento dos governados é muito superficial.

A imprensa econômica registra a "clara submissão trabalhista do capitalismo, durante os últimos quinze anos, que lhe tem permitido obter muitas vitórias". Mas adverte também que os dias de glória podem não durar por causa da crescente "campanha agressiva" dos trabalhadores "para assegurar" o assim chamado "salário mínimo" garantindo uma fatia maior do bolo.

Vale lembrar que já passamos por tudo isso anteriormente. O fim da história, a perfeição e a finalidade foram freqüentemente proclamados, sempre falsamente. E, com todas as seqüências sórdidas, penso que uma alma otimista ainda pode discernir realisticamente o progresso lento. Nos países industrializados considerados avançados, freqüentemente alhures também, lutas populares podem começar de um plano mais alto e com maiores expectativas do que nos alegres anos 90 ou loucos 20 ou mesmo há trinta anos atrás. A solidariedade internacional pode tomar formas novas e mais construtivas à medida que a grande maioria dos povos do mundo começam a compreender que seus interesses são os mesmos e que podem avançar ao trabalhar conjuntamente. Não há mais motivo agora para se acreditar que somos coagidos por leis sociais misteriosas e desconhecidas, e não por decisões simplesmente tomadas dentro de instituições sujeitas ao desejo humano - instituições humanas que têm de enfrentar o teste da legitimidade e, se elas não satisfazem, podem ser substituídas por outras, mais livres e mais justas, como freqüentemente ocorreu no passado.

Notas

1 David Hume (1711-1776), filósofo e historiador escocês, autor de A treatise of human nature e History of England.

2 Frances Hutcheson (1694-1746), filósofo do começo do século XVIII, figura proeminente do Iluminismo escocês, influenciou Hume de maneira especial. Conhecido principalmente por suas obras sobre ética e estética.

3 Franklin Harry Giddings, sociólogo norte-americano da virada do século. Razoavelmente conhecido em sua época, hoje esquecido.

4 Pais da Pátria (Founding Fathers), membros da convenção constitucionalista norteamericana de 1787: Alexander Hamilton, Benjamin Franklin, George Washington, Thomas Jefferson, John Adams, James Madison.

5 Alexander Hamilton (1757-1804), estadista norte-americano, talvez o maior advogado de sua geração. Moldou o sistema econômico norte-americano sob a Constituição.

6 Thomas Paine (1737-1804), britânico de nascimento, filósofo, político e autor. Apoiou a Revolução Francesa e teve que fugir da Inglaterra. Famoso pelas obras The rights of man e The age of reason. 
7 Lars Schoultz, scholar latino-americano de destaque, especialista em Direitos Humanos na América Latina e autor do livro mais completo e sério sobre o assunto. Professor da Universidade da Carolina do Norte.

8 Thomas Carothers, membro do setor legal do Departamento de Estado de Reagan, no qual trabalhou especificamente nos projetos de intensificação da democracia na América Latina. Autor de livros e muitos artigos sobre América Latina, Leste Europeu, problemas de democracia, entre outros.

9 John Dewey (1859-1952), filósofo e educador norte-americano.

10 Edward Bernays, um dos fundadores da Indústria de Relações Pública e nela figura de destaque do início da década de 20 até sua morte, há poucos anos. Membro do Comitê de Informação Pública de Woodrow Wilson, mais tarde um liberal de destaque do New Deal, ultimamente também ligado aos intelectuais do governo Kennedy. Autor dos primeiros e mais influentes livros da Indústria de Relações Públicas, conhecido principalmente por seu trabalho realizado nos anos 20, para popularizar o cigarro (especialmente entre mulheres) e, na década de 50, para a United Fruit Company, durante a elaboração da propaganda para a derrubada do governo de Arbens, em 1954. Altamente considerado e agraciado com honrarias por suas contribuições para o controle da opinião pública e para a teoria democrática.

$11 \mathrm{New}$ Deal, programa de reforma econômica e social introduzido pelo presidente Roosevelt, na década de 1930.

12 Walter Lippmann (1889-1974), desde a Primeira Guerra Mundial até os anos 60, figura líder do jornalismo norte-americano, também escritor e editor proeminente, um dos mais eminentes comentaristas de assuntos internacionais e um intelectual público de liderança. Também conhecido por seu trabalho sobre teoria democrática, opinião pública, política das massas, entre outros, realizado em sua maior parte nas décadas de 20 e 30. Foi um pensador liberal (no sentido norte-americano) altamente influente e advogado da causa do New Deal. Posteriormente manteve sua influência, mas ficou mais afastado de um particular espaço no espectro ideológico.

13 Harold Lasswell, um dos fundadores da ciência política acadêmica moderna, particularmente influente na área de comunicações, o primeiro estudante moderno de propaganda. O artigo citado é da Enciclopédia de Ciência Sociais, começo da década de 30.

14 Harry S. Truman (1884-1972), 33º presidente dos Estados Unidos (1945-1953). Autor do Plano Marshall, que deu ajuda econômica à Europa depois da Segunda Guerra Mundial.

15 Newt Gingrich, desde 1994 presidente da Câmara Legislativa dos Estados Unidos, deputado pela Georgia. Projetou-se internacionalmente em 1994, quando atacou a tomada da Casa pelos republicanos de ultradireita.

16 David Ricardo (1772-1823), economista inglês, o primeiro a descrever o crescimento da população.

17 Thomas Robert Malthus (1766-1834), economista inglês, famoso por seu trabalho sobre crescimento da população. 
18 Karl Polanyi, um dos historiadores econômicos e teóricos sociais importantes do século XX. Vienense, refugiado do fascismo, tornou-se professor em Oxford e na Universidade de Londres. Mais conhecido pelo seu livro The great transformations (1944) e por importante estudo crítico sobre a revolução do mercado no século XIX e suas conseqüências.

19 William Morris (1834-1896), artesão, escritor e apoiador de mudanças sociais. Formou a Liga Socialista, em 1884.

20 David Rockefeller, membro da dinastia Rockefeller, figura de destaque no mundo bancário dos Estados Unidos e de finanças internacionais. Com seu irmão, Nelson, foi uma das principais figuras do investimento dos Estados Unidos na América Latina, especialmente no Brasil. Também se destacou em assuntos internacionais e política pública.

Noam Chomsky, lingüísta, é professor titular do Instituto de Tecnologia de Massachusetts (MIT), EUA. Publicou 23 livros sobre política internacional e questões internas dos EUA.

No dia 22 de novembro de 1996, o autor fez a palestra Consentimento sem consentimento: reflexões sobre a teoria e a prática da democracia, no Auditório da Faculdade de Arquitetura e Urbanismo da USP, dentro do Ciclo Comemorativo do décimo aniversário do IEA-USP.

Tradução de Martha Steinberg. Revisão de Erasmo Garcia Mendes. O original em inglês - Consent without consent: reflections on the theory and practice of democracy - encontrase à disposição do leitor no IEA-USP para eventual consulta. 